\title{
Hyperammonemia: Regulation of Argininosuccinate Synthetase and Argininosuccinate Lyase Genes in Aggregating Cell Cultures of Fetal Rat Brain.
}

\section{Olivier Braissant ${ }^{1}$, Paul Honegger ${ }^{2}$, Marc Loup ${ }^{1}$, Katsuro Iwase ${ }^{3 *}$, Masaki Takiguchi ${ }^{3 *}$ and Claude Bachmann ${ }^{1}$.}

1 Central Clinical Chemistry Laboratory, University Hospital, CH-1011 Lausanne, Switzerland.

${ }^{2}$ Physiology Institute, University of Lausanne, CH-1011 Lausanne, Switzerland.

${ }^{3}$ Department of Molecular Genetics, Kumamoto University School of Medicine, Kumamoto 862-0976, Japan.

* Present address: Department of Biochemistry, Chiba University School of Medicine, Chiba 260-8670, Japan

Keywords: brain, argininosuccinate, arginine, citrulline-NO cycle, astrocyte, hyperammonemia

\section{Correspondence to :}

Olivier Braissant

Central Clinical Chemistry Laboratory,

University Hospital,

CH-1011 Lausanne, Switzerland

Tél : (+41.21) 314.41.52

Fax : (+41.21) 314.42.88

e-mail : Olivier.Braissant@chuv.hospvd.ch 


\begin{abstract}
Hyperammonemia in the brain leads to poorly understood alterations of nitric oxide (NO) synthesis. Arginine, the substrate of nitric oxide synthases, might be recycled from the citrulline produced with NO by argininosuccinate synthetase (AS) and argininosuccinate lyase (AL). The regulation of AS and AL genes during hyperammonemia is unknown in the brain. We used brain cell aggregates cultured from dissociated telencephalic cortex of rat embryos to analyse the regulation of AS and AL genes in hyperammonemia. Using RNase protection assay and non-radioactive in situ hybridization on aggregate cryosections, we show that both AS and AL genes are induced in astrocytes but not in neurons of aggregates exposed to $5 \mathrm{mM} \mathrm{NH}_{4} \mathrm{Cl}$. Our work suggests that the hyperammonemic brain might increase its recycling of citrulline to arginine.
\end{abstract}


Inherited disorders of the urea cycle enzymes or liver insufficiency, be it acute or chronic, lead to accumulation of ammonia and to deficiency of arginine (except for arginase deficiency). In central nervous system (CNS), these conditions lead to reversible and irreversible changes, the mechanisms of which are poorly understood. The reversible neurological symptoms of hyperammonemia have been partly explained by the cerebral detoxication of ammonia through increased formation of glutamate and glutamine [7;14] which leads to increased uptake of large neutral amino acids including tryptophan [3]. This results in a rise of serotonin concentration and flux in the brain [3;6]. Other alterations, affecting glutamatergic, cholinergic and GABAergic neurotransmission, energy metabolism, astrocyte morphology as well as glutamate uptake, have also been described in the hyperammonemic brain [5;11].

Arginine synthesis from citrulline is catalyzed by the two cytosolic urea cycle enzymes argininosuccinate synthetase (AS) and argininosuccinate lyase (AL). There is no de novo synthesis of arginine from ammonia and ornithine in CNS, since the mitochondrial urea cycle enzymes carbamoylphosphate synthetase (CPS) and ornithine transcarbamylase (OTC) are not expressed in the brain. However, citrulline is produced in CNS by nitric oxide synthases (NOS), in the reaction forming nitric oxide (NO) from arginine. Citrulline might be recycled to arginine through the CNS expression of AS and AL [2;10]. NOS, AS and AL constitute the so-called citrulline-NO cycle. Thus, for fulfilling their needs in arginine, brain cells depend on specific transporters to import arginine from the blood [15;17], and on the expression of AS and AL. The analysis of the regulation of the citrulline-NO cycle in hyperammonemia, and especially of AS and AL genes, is of particular interest, since in experimental hyperammonemia NOS activity is increased in different brain regions together with an augmentation of the cell uptake of L-arginine [13]. Moreover, OTC deficient spf/Y mice, a model of human urea cycle genetic disorders, develop hyperammonemia and present a significant decrease in CNS arginine concentration [14].

In order to study the potential regulation of AS and AL genes in the hyperammonemic CNS, we used primary brain cell aggregate cultures issued from the cortex of rat embryos [8], exposed to $5 \mathrm{mM}$ ammonium chloride.

Reaggregated brain cell primary cultures were prepared from mechanically dissociated telencephalons of 16 day old rat embryos and grown in serum-free chemically defined 
DMEM containing high glucose (25 mM) [8]. L-arginine concentration was $400 \mu \mathrm{M}$. Cultures were grown for 21 days and treated from day 5 with $5 \mathrm{mM} \mathrm{NH}_{4} \mathrm{Cl}$ (or $5 \mathrm{mM} \mathrm{NaCl}$ for controls). Medium was renewed at days 8 and 11 (5 ml replaced out of $8 \mathrm{ml}$ total). Day 13 aggregates were washed in PBS and prepared for RNA extraction or embedded for histology.

cDNAs from rat AS [16], AL [1] and ribosomal protein L27 (used for internal control, [9]) were obtained by RT-PCR and used for RNase protection assay (RPA) using antisense [ $\alpha$ ${ }^{32}$ P]UTP-labeled riboprobes [9] (probe length: AS 363 nt, AL 434 nt, L27 270 nt; protected fragment length: AS 334 nt, AL 405 nt, L27 $220 \mathrm{nt})$. Specific activities were $10^{9} \mathrm{cpm} / \mu \mathrm{g}\left(10^{11}\right.$ $\mathrm{cpm} / \mathrm{nmol})$ for AS and AL and $10^{8} \mathrm{cpm} / \mu \mathrm{g}\left(10^{10} \mathrm{cpm} / \mathrm{nmol}\right)$ for L27. $8 \mu \mathrm{g}$ of total RNA were hybridized with $1 \mathrm{ng}$ of AS or AL riboprobes and $10 \mathrm{ng}$ of L27 riboprobe. After separation on polyacrylamide gel and exposure to x-ray film, autoradiograms were scanned for the measure of steady state mRNAs levels.

For histology, aggregates were embedded in tissue freezing medium, frozen in isopentane and dry ice, and analyzed by in situ hybridization (ISH) as described [4]. Briefly, cryosections 12 $\mu \mathrm{m}$ thick were hybridized with digoxigenin-labelled antisense and sense riboprobes for rat AS and AL. Hybridization $\left(58^{\circ} \mathrm{C}\right.$ for $40 \mathrm{~h}$ in $5 \mathrm{xSSC}$ and $50 \%$ formamide), washes (30min in 2xSSC at room temperature, $1 \mathrm{~h}$ in $2 \mathrm{xSSC}$ at $65^{\circ} \mathrm{C}$, $1 \mathrm{~h}$ in $0.1 \mathrm{xSSC}$ at $65^{\circ} \mathrm{C}$ ), alkalinephosphatase staining (15h) and mounting of the slides were done as described [4]. The specificity of hybridization was controlled with the corresponding sense probes for AS and AL. Astrocytes and neurons were characterized by immunohistochemistry using monoclonal antibodies against glial fibrillary acidic protein (GFAP) and microtubule associated protein 2 (MAP2) respectively, stained with a secondary anti-mouse IgG bridging antibody together with a tertiary alkaline phosphatase / anti-alkaline phosphatase complex. A May-Grünwald coloration was performed for overall staining of the aggregates.

Exposing the cultures to $\mathrm{NH}_{4} \mathrm{Cl}$ resulted in an increased consumption of glucose and production of lactate, particularly between days 8 and 11 (Table 1). $\mathrm{NH}_{4} \mathrm{Cl}$ treated aggregates reduced ammonia concentration in the medium, at maximum between days 8 and 11, from 4.5 to $1.1 \mathrm{mM}$ (Table 1). General effects of $\mathrm{NH}_{4} \mathrm{Cl}$ treatments were surveyed up to 21 days by measuring enzymatic activities of glutamic acid decarboxylase (GAD, GABA-ergic neurons), choline acetyltransferase (ChAT, cholinergic neurons) and glutamine synthase (GS, astrocytes), as well as protein content [8]. $\mathrm{In} \mathrm{NH}_{4} \mathrm{Cl}$ treated cultures, GAD total activity per 
culture $(\mathrm{n}=3)$ was decreased $(800 \pm 90$ versus $1230 \pm 210 \mathrm{pmol} / \mathrm{min})$, whereas ChAT $(370 \pm 40$ versus $410 \pm 80 \mathrm{pmol} / \mathrm{min})$ and GS (230 \pm 20 versus $300 \pm 40 \mathrm{nmol} / \mathrm{min})$ were moderately reduced. The protein content of $\mathrm{NH}_{4} \mathrm{Cl}$ treated cultures was lower than in controls $(1.20 \pm 0.20$ versus $1.90 \pm 0.30 \mathrm{mg}$ protein/culture).

In both conditions, the AS transcript was barely detectable by RPA and could not be quantitated reliably by densitometry (Fig. 1A). The AL mRNA steady state level was 2.8 times higher in $\mathrm{NH}_{4} \mathrm{Cl}$ treated aggregates than in controls, relatively to the ribosomal protein L27 transcript level (Fig. 1B,C).

Normal day 13 aggregates presented a characteristic distribution of cell types. Neurons of big size were organized in a sub-peripheral ring (Fig. 2I, arrowhead) and extended their dendrites towards the periphery of the aggregate, as shown by the densely packed fibers stained for MAP2 (Fig. 2E, asterisk). Astrocytes were evenly distributed in the aggregate (Fig. 2F,I, arrow). Aggregates treated with $5 \mathrm{mM} \mathrm{NH}_{4} \mathrm{Cl}$ showed a significant reduction in size, which fitted the decrease in protein mentioned above. Cells did not seem to have changed in number, but were more densely packed within the aggregate. The peripheral dense fiber zone was reduced (Fig. 2E,G,I,K, asterisk) and neuron cell bodies were more peripheral (Fig. 2E,G). As in control aggregates, astrocytes were distributed evenly, but exhibited a higher GFAP immunoreactivity (Fig. 2F,H).

ISH was more sensible than RPA, and allowed us to localize both AS and AL mRNAs. In control aggregates, the AS gene was expressed at low levels and not detectable in the peripheral dense fiber zone (Fig. 2A,E). It was located both in neurons and astrocytes (Fig. 2E,F,I). In $\mathrm{NH}_{4} \mathrm{Cl}$ treated aggregates, the AS gene expression was induced in cells identified as astrocytes (Fig. 2C,G,H,K). In the other cells, the low expression of the AS gene was maintained at levels found in controls. In control aggregates, the AL mRNA was expressed ubiquitously at low levels (Fig. 2B), and was located in both neurons and astrocytes (Fig. 2E,F,I). The AL transcript was present in the peripheral dense fiber zone, contrary to the AS mRNA (Fig. 2A,B,E). In $\mathrm{NH}_{4} \mathrm{Cl}$ treated aggregates, $\mathrm{AL}$ expression was predominantly increased in astrocytes, as the AS gene (Fig. 2D,G,H,K). As found for AS, a low expression of AL was maintained in the other cells. No signal could be detected on aggregate sections hybridized with the respective AS and AL sense control probes (Fig. 2J,L).

This is the first report of AS and AL gene regulation by ammonia in brain cells, showing that 
both genes are induced in astrocytes under $\mathrm{NH}_{4} \mathrm{Cl}$ treatment. In the normal rat brain, AS has been localized by immunohistochemistry in some but not all neurons, whereas AL was found in a specific glial subtype of cerebellum, as well as ubiquitously in neurons [2;10]. During hyperammonemia, the NO production was found increased in brain synaptosomes, in parallel with an augmentation of their arginine uptake [13]. Our present findings suggests that under hyperammonemic conditions, the CNS gene expression of AS and AL is enhanced in astrocytes, which could allow a more efficient recycling of citrulline to arginine, the unique precursor of NO.

In rat hepatocytes, the AS gene is up-regulated under increasing glutamine in the medium, but not by increased ammonia, in contrast to our present findings in brain [12]. The tissue differences of AS and AL gene expression and activities under hyperammonemia might provide clues to the understanding of the molecular mechanisms of AS and AL gene regulation by ammonia. Among these, membrane transport of citrulline and arginine between neurons and astrocytes, regulation of NOS activity and arginine utilization should be included.

We thank Drs. M. Mori and H. Henry for a critical reading of the manuscript and fruitful discussions.

[1] Amaya, Y., Matsubasa, T., Takiguchi, M., Kobayashi, K., Saheki, T., Kawamoto, S. and Mori, M., Amino acid sequence of rat argininosuccinate lyase deduced from cDNA, J.Biochem., 103 (1988) 177-181.

[2] Arnt-Ramos, L.R., O'Brien, W.E. and Vincent, S.R., Immunohistochemical localization of argininosuccinate synthetase in the rat brain in relation to nitric oxide synthasecontaining neurons, Neuroscience, 51 (1992) 773-789.

[3] Bachmann, C., Ornithine carbamoyl transferase deficiency: findings, models and problems, J.Inherit.Metab.Dis., 15 (1992) 578-591.

[4] Braissant, O., Foufelle, F., Scotto, C., Dauça, M. and Wahli, W., Differential expression of peroxisome proliferator-activated receptors (PPARs): tissue distribution of PPARalpha, -beta, and -gamma in the adult rat, Endocrinology, 137 (1996) 354-366.

[5] Butterworth, R.F., Effects of hyperammonemia on brain function, J.Inherit.Metab.Dis., 21 (1998) 6-20.

[6] Colombo, J.P., Bachmann, C., Cervantes, H., Kokorovic, M. and Perritaz, R., Tyrosine 
uptake and regional brain monoamine metabolites in a rat model resembling congenital hyperammonemia, Pediatr.Res., 39 (1996) 1036-1040.

[7] Hawkins, R.A., Miller, A.L., Nielsen, R.C. and Veech, R.L, The acute action of ammonia on rat brain metabolism in vivo, Biochem.J., 134 (1973) 1001-1008.

[8] Honegger, P. and Monnet-Tschudi, F., Aggregating neural cell culture. In S.Fedoroff and A. Richardson (Eds.), Protocols for neural cell culture, Humana Press, Totowa NJ, 1997, pp. 25-49.

[9] Lemberger, T., Staels, B., Saladin, R., Desvergne, B., Auwerx, J. and Wahli, W., Regulation of the peroxisome proliferator-activated receptor alpha gene by glucocorticoids, J.Biol.Chem., 269 (1994) 24527-24530.

[10] Nakamura, H., Saheki, T. and Nakagawa, S., Differential cellular localization of enzymes of L-arginine metabolism in the rat brain, Brain Res., 530 (1990) 108-112.

[11] Norenberg, M.D., Huo, Z., Neary, J.T. and Roig-Cantesano, A., The glial glutamate transporter in hyperammonemia and hepatic encephalopathy: relation to energy metabolism and glutamatergic neurotransmission, Glia, 21 (1997) 124-133.

[12] Quillard, M., Husson, A. and Lavoinne, A., Glutamine increases argininosuccinate synthetase mRNA levels in rat hepatocytes. The involvement of cell swelling, Eur.J.Biochem., 236 (1996) 56-59.

[13] Rao, V.L., Audet, R.M. and Butterworth, R.F., Increased nitric oxide synthase activities and L- $\left[{ }^{3} \mathrm{H}\right]$ arginine uptake in brain following portacaval anastomosis, J.Neurochem., 65 (1995) 677-678.

[14] Ratnakumari, L., Qureshi, I.A. and Butterworth, R.F., Regional amino acid neurotransmitter changes in brains of $\mathrm{spf} / \mathrm{Y}$ mice with congenital ornithine transcarbamylase deficiency, Metab.Brain Dis., 9 (1994) 43-51.

[15] Schmidlin, A. and Wiesinger, H., Transport of L-arginine in cultured glial cells, Glia, 11 (1994) 262-268.

[16] Surh, L.C., Morris, S.M., O'Brien, W.E. and Beaudet, A.L., Nucleotide sequence of the cDNA encoding the rat argininosuccinate synthetase, Nuc.Acids Res., 16 (1988) 9352.

[17] Westergaard, N., Beart, P.M. and Schousboe, A., Transport of L- $\left[{ }^{3} \mathrm{H}\right]$ arginine in cultured neurons: characteristics and inhibition by nitric oxide synthase inhibitors, J.Neurochem., 61 (1993) 364-367. 
Table 1: Glucose, lactate and ammonia in culture medium. Treatments with $5 \mathrm{mM} \mathrm{NaCl}$ (control) or $5 \mathrm{mM} \mathrm{NH}_{4} \mathrm{Cl}$ from day 5 to 13. Medium was renewed at days 8 and 11, by replacement of $5 \mathrm{ml}$ on a total of $8 \mathrm{ml}$. Measures of glucose, lactate and ammonia [mM] were done after renewal of medium (days 8 and 11, measure I: initial), and before renewal of medium (day 11) or recovery of the aggregates (day 13)(measure F: final). Consumption or production between days 8 and 11 as well as between days 11 and 13 are given (F-I, [ $\mu \mathrm{mol} /$ day/culture]). Mean $\pm \mathrm{SD}, \mathrm{n}=3$.

\begin{tabular}{|c|c|c|c|c|}
\hline & & I & $\mathrm{F}$ & F-I \\
\hline $\begin{array}{c}\text { Glucose } \\
\text { days 8-11 } \\
\text { " }\end{array}$ & $\begin{array}{c}\mathrm{NaCl} \\
\mathrm{NH}_{4} \mathrm{Cl}\end{array}$ & $\begin{array}{l}19.3 \pm 0.2 \\
18.1 \pm 0.1\end{array}$ & $\begin{array}{l}6.4 \pm 0.3 \\
2.8 \pm 0.3\end{array}$ & $\begin{array}{l}-34.5 \pm 0.4 \\
-40.9 \pm 0.7\end{array}$ \\
\hline $\begin{array}{c}\text { days } 11-13 \\
\text { " }\end{array}$ & $\begin{array}{c}\mathrm{NaCl} \\
\mathrm{NH}_{4} \mathrm{Cl}\end{array}$ & $\begin{array}{l}18.0 \pm 0.1 \\
16.7 \pm 0.1\end{array}$ & $\begin{array}{l}3.0 \pm 0.5 \\
3.9 \pm 0.2\end{array}$ & $\begin{array}{l}-60.2 \pm 1.6 \\
-50.9 \pm 0.8\end{array}$ \\
\hline $\begin{array}{c}\text { Lactate } \\
\text { days 8-11 } \\
0\end{array}$ & $\begin{array}{c}\mathrm{NaCl} \\
\mathrm{NH}_{4} \mathrm{Cl}\end{array}$ & $\begin{array}{l}3.5 \pm 0.1 \\
5.2 \pm 0.1\end{array}$ & $\begin{array}{c}9.2 \pm 0.2 \\
18.9 \pm 1.2\end{array}$ & $\begin{array}{l}15.3 \pm 0.7 \\
36.5 \pm 3.3\end{array}$ \\
\hline $\begin{array}{c}\text { days } 11-13 \\
\text { " }\end{array}$ & $\begin{array}{c}\mathrm{NaCl} \\
\mathrm{NH}_{4} \mathrm{Cl}\end{array}$ & $\begin{array}{l}3.5 \pm 0.1 \\
7.1 \pm 0.5\end{array}$ & $\begin{array}{l}16.5 \pm 0.6 \\
21.7 \pm 0.4\end{array}$ & $\begin{array}{l}52.1 \pm 2.2 \\
58.5 \pm 1.2\end{array}$ \\
\hline $\begin{array}{c}\text { Ammonia } \\
\text { days 8-11 } \\
\end{array}$ & $\begin{array}{c}\mathrm{NaCl} \\
\mathrm{NH}_{4} \mathrm{Cl}\end{array}$ & $\begin{array}{l}0.29 \pm 0.01 \\
4.50 \pm 0.05\end{array}$ & $\begin{array}{l}0.13 \pm 0.01 \\
1.10 \pm 0.50\end{array}$ & $\begin{array}{l}-0.42 \pm 0.01 \\
-9.10 \pm 1.30\end{array}$ \\
\hline $\begin{array}{c}\text { days } 11-13 \\
\text { " }\end{array}$ & $\begin{array}{c}\mathrm{NaCl} \\
\mathrm{NH}_{4} \mathrm{Cl}\end{array}$ & $\begin{array}{l}0.22 \pm 0.01 \\
3.70 \pm 0.20\end{array}$ & $\begin{array}{l}0.17 \pm 0.01 \\
3.00 \pm 0.50\end{array}$ & $\begin{array}{l}-0.21 \pm 0.03 \\
-2.70 \pm 1.80\end{array}$ \\
\hline
\end{tabular}




\section{Figure legends:}

Fig. 1: Expression of AS, AL and L27 mRNAs in day 13 aggregates. RNase protection assay for AS/L27 (A) or AL/L27 (B). Treatment from day 5 to 13 with $5 \mathrm{mM} \mathrm{NaCl}$ (-) or 5 $\mathrm{mM} \mathrm{NH}_{4} \mathrm{Cl}(+)$. Non-digested probes for AS (1), AL (2) and $\mathrm{L} 27$ (3). Protected fragments indicated by arrows. Gels loaded with $8 \mu \mathrm{g}$ of total RNA were exposed 14 days (A) and 3 days (B). C: The graph illustrates the $\mathrm{AL}$ gene induction in $\mathrm{NH}_{4} \mathrm{Cl}$ treated aggregates (mean \pm $\mathrm{SD}, \mathrm{n}=3$ ). The very low expression of AS did not allow any reliable densitometric quantification.

Fig. 2: Cell type specific expression of AS and AL mRNAs in day 13 aggregates. In situ hybridization with antisense probes for AS (A,C) and AL (B,D) and sense probes for AS (J) and AL (L). Immunohistochemistry for MAP2 (E,G) and GFAP (F,H). May-Grünwald coloration (I,K). Aggregates treated from day 5 to 13 with $5 \mathrm{mM} \mathrm{NaCl}$ (controls, A,B,E,F,I,J) or $5 \mathrm{mM} \mathrm{NH}_{4} \mathrm{Cl}(\mathrm{C}, \mathrm{D}, \mathrm{G}, \mathrm{H}, \mathrm{K}, \mathrm{L})$. Neurons are indicated by arrowheads, astrocytes by arrows, and the dense peripheral fiber zone by asterisks. Pictures J and L (sense control probes) taken in Nomarski optic. Bar: $100 \mu \mathrm{m}$. 
Figure 1 :

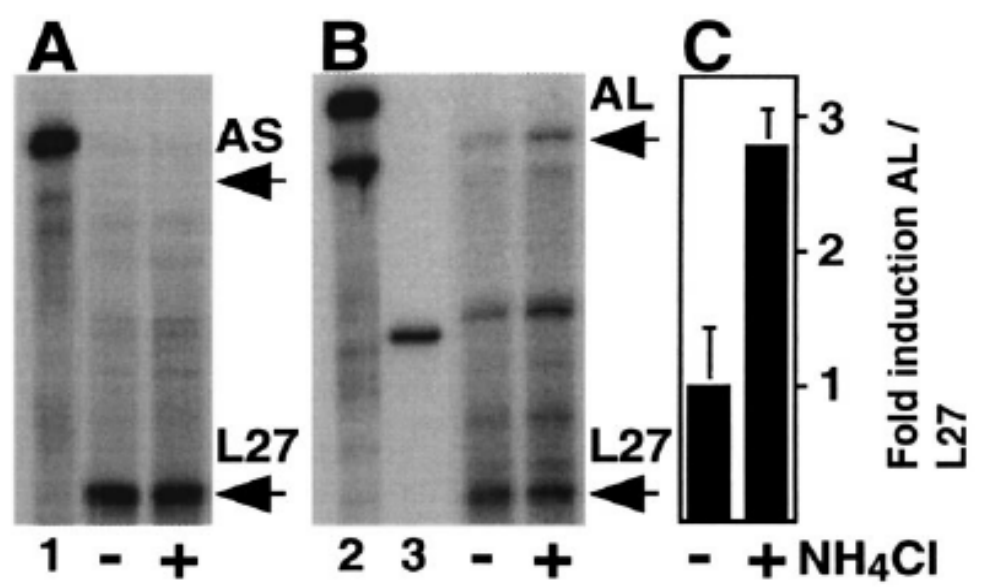

Figure 2 :
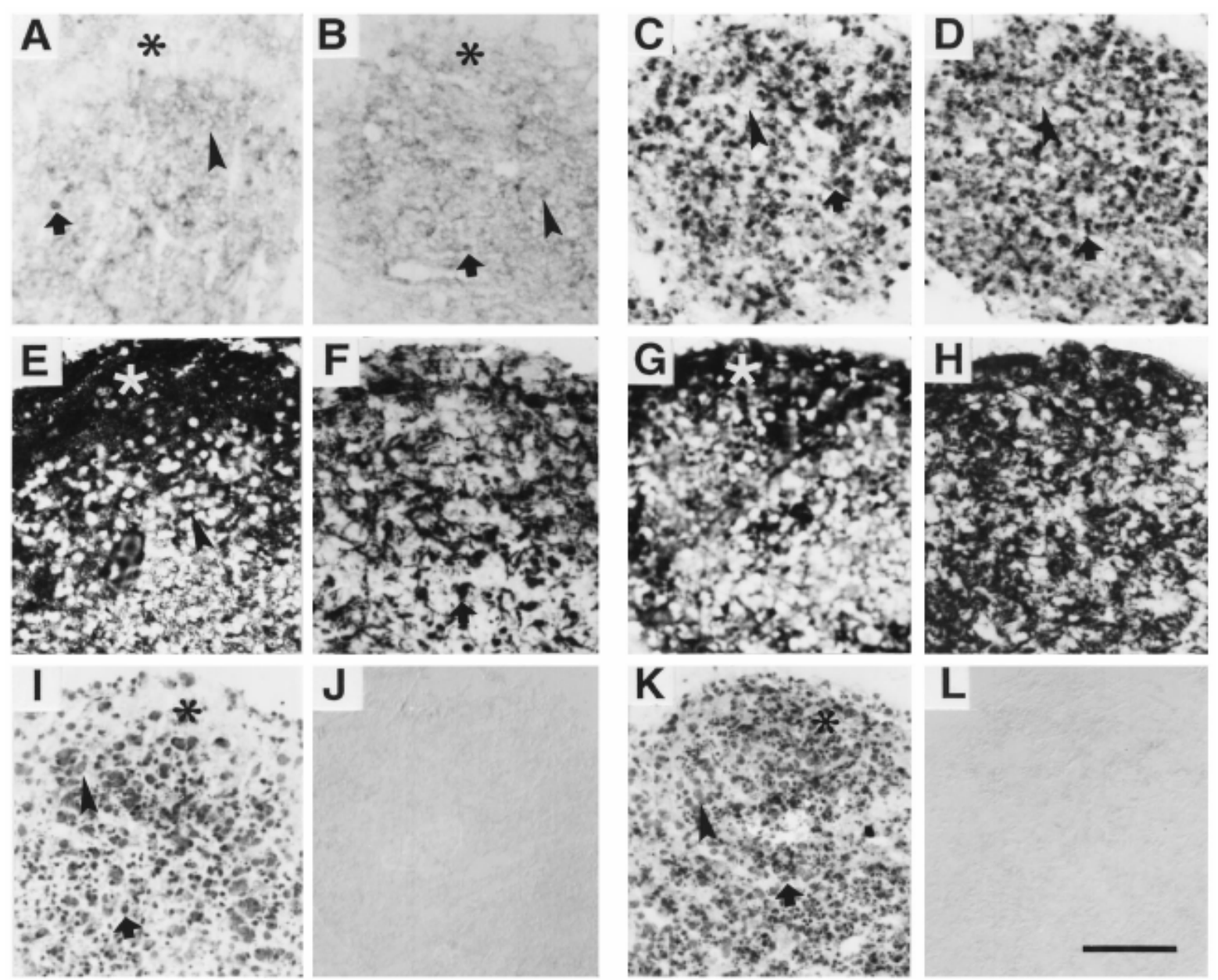

L 